\title{
Legal and economic thought in retrospect: a new facet of intellectual history
}

\section{A. M. Lushnikov ${ }^{1}$}

${ }^{1}$ P. G. Demidov Yaroslavl State University, 14 Sovetskaya str., Yaroslavl 150003, Russian Federation

DOI: $10.18255 / 1996-5648-2021-2-194-201$

Research article Full text in Russian

This article examines such a little-studied problem as the interaction of legal and economic thought in retrospect. New approaches to the study of this interactionareoutlined.Theresearchis based on historical,systemicand structural and comparative legal scientific methods. The author substantiatedly asserts about the chronological primacy of legal research, in connection with which the appeal to the study of economics was of a subordinate nature. It is noted that the research of that period was mainly of a normative nature, since their authors wanted to define a model of behavior in the field of economics, which would correspond to the ideals of natural law. Special attention is paid to the modern problems of interaction between legal and economic thought. In this regard, «economic imperialism» is subjected to well-reasoned criticism, according to which the laws of the economy apply to all spheres of social life. It is concluded that the study of the interaction of legal and economic thought in retrospect makes it possible not only to better understand the processes taking place in the past, but also to consider the directions of solutions to modern problems facing the legal and economic sciences.

Keywords: intellectual history; legal science; economic science; natural law

\section{INFORMATION ABOUT AUTHORS}

Lushnikov, Andrey M. | E-mail: amlu0909@yandex.ru

Doc. Sc. (Jurisprudence), Doc. Sc. (History), Professor, Head of the Chair

Funding: Yaroslavl State University, Project VIP-014. 


\section{Правовая и экономическая мысль в ретроспективе: новая грань интеллектуальной истории}

\section{А. М. Лушников ${ }^{1}$}

${ }^{1}$ Ярославский государственный университет им. П. Г. Демидова, ул. Советская, 14, Ярославль, 150003, Российская Федерация

DOI: $10.18255 / 1996-5648-2021-2-194-201$ УДК 340

Научная статья Полный текст на русском языке

В данной статье рассмотрена такая малоисследованная проблема, как взаимодействие правовой и экономической мысли в ретроспективе. Намечаются новые подходы к изучению этого взаимодействия. В основу исследования положены исторический, системно-структурный и сравнительно-правовой научные методы. Автор обоснованно утверждает о хронологическом первенстве правовых исследований, в связи с чем обращение к изучению экономики носило подчиненный характер. Отмечается, что исследования того периода имели специфику преимущественно нормативного характера, т. к. их авторы хотели определить модель поведения в сорере экономики, которая бы соответствовала идеалам естественного права. Особое внимание уделено современной проблематике взаимодействия правовой и экономической мысли. В этом плане аргументированной критике подвергнут «экономический империализм», в соответствии с которым закономерности экономики распространяются на все сореры общественной жизни. Сделан вывод, что исследование взаимодействия правовой и экономической мысли в ретроспективе позволяет не только лучше понять процессы, происходящие в прошлом, но и рассмотреть направления решений современных задач, стоящих перед правовой и экономической науками.

Ключевые слова: интеллектуальная история; юридическая наука; экономическая наука; естественное право

\section{ИНФОРМАЦИЯ ОБ АВТОРАХ}

Лушников, Андрей Михайлович

E-mail: amlu0909@yandex.ru

Доктор юридических наук, доктор исторических

наук, профессор, заведующий кафедрой

Финансирование: ЯрГУ, проект VIP-014.

В интеллектуальной истории, как и в любом другом разделе исторической науки, особого внимания заслуживает рассмотрение “стыковых" проблем между науками. В этом сложном междисциплинарном переплете(с) Лушников А. М., 2021

Статья открытого доступа под лицензией CC BY (https://creativecommons.org/licenses/by/4.0/) 
Лушников А. М.

нии важное место занимает взаимодействие правой и экономической мысли. Общие подходы к такому взаимодействию мы уже отчасти обозначали ранее [1]. При этом в любом случае юриспруденция как хронологически, так и проблемно в этом процессе предшествовала экономической науке, а потребности именно правового регулирования во многом стимулировали экономические исследования. Эта очевидная истина признается не только правоведами, но и специалистами в сорере экономики [2, с. 6-7; 3, с. 127-128]. Так, немецкий экономист Г. Шмоллер прямо утверждал, что политическая экономия была построена на началах естественного права [4, с. 153]. Впоследствии эта тенденция связывалась с влиянием естественно-правовой доктрины. Отсюда и ярко выраженный поиск исследователями экономических проблем, включая схоластов, меркантилистов и камералистов, а затем и экономистов-классиков, «естественных законов», управляющих экономикой, подобных «естественному праву», на которое должно ориентироваться человеческое поведение.

В российской экономической науке уже на рубеже XIX-XX вв. признание огромного влияния естественного права на экономику было аксиоматичным и никем не оспаривалось. Например, по утверждению российского финансиста М. В. Бернацкого, «в основе общественно-политических систем физиократов и А. Смита, создавших политическую экономию как науку, лежит идея “естественного порядка", предуказанного природой и требующего, во имя благоденствия людей, своего осуществления в порядке положительном. Это является развитием в отношении экономики доктрины “естественного права", сыгравшего такую громадную роль в эволюции дисциплины права» [5, с. 1]. Отечественный экономист М. И. Туган-Барановский соглашался с мнением о том, что «система теоретической экономической науки постепенно развивалась из составной части естественного права» [6, с. 23]. В соответствии с данным подходом исследователи экономики в рамках естественно-правовой традиции занимались не столько описанием и интерпретацией ее фрункционирования, сколько созданием морально приемлемых правил поведения и регулирования общественных отношений в области экономики. Это придавало их работам в значительной части нормативный характер, хотя и позитивная составляющая была ярко выражена.

Таким образом, первоначально экономика была ответвлением нравственной философии, связанной с юриспруденцией в широком смысле. Это была одновременно и моральная наука, и наука об обществе. Напомним, что первый в Европе Болонский университет был сорормирован на базе школы права в конце XI в., а юридические фракультеты с соответствующей профессурой присутствовали изначально в структуре практически всех университетов. Многие века основы экономических знаний в той или иной мере преподавались преимущественно именно на юридических фракультетах. Первые профрессора-экономисты появились в Герма- 
нии только в первой половине XVIII в., а вне Германии - вообще в первой половине XIX в. Первым профрессором экономики считается С. П. Гассер, получивший это звание в 1727 г. Создание первой университетской кафредры политической экономии датируется 1754 г. (Неаполь), возглавлял эту кафедру А. Дженовези. Первая кафедра политической экономии в Англии создается только в 1805 г. в колледже, открытом Ост-Индской компанией в Хейлибери. Специальные кафедры экономики в ведущих британских университетах появились на рубеже XIX-XX вв.

В целом экономика даже в станах Запада стала академическим предметом лишь в 1880-е гг. [7, с. 2-3], а в Италии, как и в некоторых других странах Запада, центр преподавания экономики покинул фракультеты права вообще только после завершения Второй мировой войны. По мнению современного итальянского ученого А. Ронкалья, экономисты достаточно долго представляла собой скорее интеллектуалов, которые рассматривают экономические вопросы наряду с прочими проблемами [8, с.14-46, 137, 435]. В отношении Великобритании американский историк Д. А. Тейлор был еще более категоричен: «В начале XIX столетия, другими словами после Смита, классическая экономика в Британии была полупрофрессиональной и полуакадемической дисциплиной, строившейся по немецкому образцу, и одновременно на половину оставалась любительством, бессистемным занятием джентльменов, обладавших сильным чувством общественного долга, но, в лучшем случае, имевшим весьма приблизительные представления о торговле» [9, с. 62]. Отметим, что среди этих интеллектуалов и джентльменов преобладали юристы, а также встречались врачи, государственные деятели, священники и др.

Подчеркнем, что это свидетельствует только о том, что проблематика экономической науки имеет до известной степени комплексный, многосторонний характер, а в некоторой части и изначально междисциплинарный аспект. Она связана, что называется, с "хлебом насущным», благосостоянием отдельных индивидов и всего общества. Это и делает ее открытой для интенсивного диалога представителей разных наук.

В этой связи стоит подходить к научному наследию экономистов прошлого с несколько иной меркой, чем это делают некоторые представители современной неоклассики, особенно из числа молодых исследователей. Постоянные сетования на то, что тот или иной ученый в свое время «не создал математической модели», «не дорос до теории предельной полезности», «не оценил тотального влияния экономики на все сфреры общественной жизни», «не составил графиков», «не начертил кривые» и др. кажутся нам неуместными и даже нелепыми. Практически все выдающиеся экономисты до начала XX в. были высокими профессионалами, однако, как правило, в области права, фрилософии, социологии и др. Именно этим определялось своеобразие их подхода к проблемам экономики. 
Лушников А. М.

Более того, даже само выделение самостоятельной экономической науки было следствием в том числе интенсивного развития других наук, особенно фрилософии и правоведения, фрормирования соответствующей интеллектуальной среды. Так, зарождение политической экономии именно в Великобритании во второй половине XVIII в. как раз и связано с тем, что там существовал относительно высокий уровень развития правоведения и правовой культуры, соответствующая духовная атмосфера («Шотландское Просвещение», наличие системы высшего образования, относительная свобода мысли и др.), которые позволили проводить экономические исследования и осуществлять эффрективную экономическую деятельность. Этому способствовали и такие правовые феномены, как патентная система и защита авторских прав, независимые суды и сильная адвокатура, закрепление и защита права собственности, стабильное финнансовое право, зачатки трудового законодательства. Таким образом, цепь политических событий и правовых преобразований - от захвата Англии Вильгельмом Завоевателем в 1066 г. до Славной революции 1688 г. - привела к появлению экономической науки именно в этом регионе Европы.

Ситуация для взаимодействия правовой и экономической мысли в дальнейшем упрощалась еще и потому, что профессионально экономикой по-прежнему занимались преимущественно юристы по образованию (начиная от А. Смита). В силу этого особой необходимости в изучении раздельно правовой и экономической мысли и не было. Разрыв между экономикой и правом начал расширяться в 20-40-е гг., усилился в 50-е гг. [10, с. 37-56], превратившись почти в пропасть к концу 70-х гг. XX в. Естественно, это движение началось уже после 1870 г. и связано с т. н. «маржиналистской революцией», когда предметом экономики стало «человеческое поведение как отношение между данными целями и ограниченными средствами, имеющими альтернативную возможность применения» [11, с. 146]. Экономическая наука стала концентрироваться на принципах, согласно которым осуществляется эффективное распределение ресурсов при условии, что и ресурсы, и потребности известны заранее. Впрочем, маржинализм был достаточно неоднородным, да и его ответвления в дальнейшем были крайне разнообразны. Однако в любом случае произошел переход от классической микро- и макроэкономики к неоклассической микроэкономике.

Более того, до недавнего времени среди мейстримовских экономистов- неоклассиков был популярным (а у некоторых остался и сейчас) «экономический империализм». За этим милым названием скрывается научное направление, основанное на том, что законам и аксиомам экономики подчиняется человеческое поведение не только в сорере экономики, но и во всех сфрерах общественной жизни и они должны быть положены в основу изучения предмета любой гуманитарной науки - от истории и философии до социальной психологии и антропологии. Дело дошло до того, что история экономической мысли, написанная экономистами, достаточ- 
но сильно отличается от истории экономической мысли, подготовленной историками. Мы уже не говорим про многочисленные изыски экономистов в духе «экономики права», «экономики истории», а равно «экономики всего на свете» (скромники -экономисты ограничиваются «экономикой почти всего на свете»).

Это тем более странно, что экономисты, к сожалению, далеко не всегда могут разобраться со своей традиционной проблематикой, возможно излишне увлекаясь разъяснением другим жизненной важности экономического подхода. Свидетельство тому - разночтения в оценке как прошлого, так и относительно недавних событий, например экономический кризис 2008 г., который по одной версии окончился в 2012 г., а по другой - медленно перерастает в новый. В этой связи стоит согласиться с корейским экономистом и кембриджским профессором Х. Д. Чангом в том, что $95 \%$ экономической теории - это всего лишь здравый смысл, которому придали сложный вид с помощью специальной терминологии и математики. От себя добавим, что степень этой сложности и математизация зачастую чрезвычайно излишни и скрывают либо эфемерное содержание, либо очередную банальность. Кроме того, «экономическая теория страдает манией величия - разве способна наука, которая не в состоянии разобраться даже в собственной сфрере применения, заявлять, что она объясняет все или почти все?» $[12$, с. 8,15$]$. В этой связи стоит вспомнить и слова французского антрополога и социолога Л. Дюмона: «Мы, по всей видимости, слишком долго рассматривали экономические вопросы в качестве вопросов цели и теперь настал момент вернуть экономике статус средства, служащего истинным человеческим целям, а именно целям социальным» [13, с. 121].

Опыт второй половины XX в. пестрит примерами неудачного взаимодействия в интеллектуальной сфере экономистов с другими гуманитариями, когда сторонники радикальной рыночной экономики не могли ужиться в рамках одной структуры вообще ни с кем, включая социально ориентированных экономистов. Так, Лондонская школа экономики и политических наук, созданная в 1895 г., задумывалась своими основателями как центр социальных исследований с целью «улучшения общества». Примечательно, что среди этих основателей были Б. Вебб и С. Вебб, являвшиеся сторонниками британской версии социализма. Однако постепенно ведущее место в ней заняли радикальные экономисты- рыночники, как, например, Л. Роббинс и Ф. А. Хайек. В итоге в 30-х гг, а затем в 70-80-х гг. ХХ в. эта школа стала британским центром рыночных фрундаменталистов, а затем и идейных вдохновителей тетчеризма. Эти экономисты оказались самыми «громкими» в медийной сфрере, затмив социологов, юристов и политологов, которые в значительной степени и составили высокую репутацию вуза, вошедшего в 1900-е г. в структуру Лондонского университета и много лет стабильно котировавшегося в числе первых трех университетов Англии. Дело дошло до того, что и само название на обыденном уровне уполовинили до «Лондон- 
Лушников А. М.

ской школы экономики», превратив остальные «политические науки» в разновидность экономических.

Еще более показателен опыт общества «Мон Пелерин», созданного в 1947 г. в Швейцарии в качестве международной организации интеллектуалов - сторонников идей индивидуальной свободы, рыночной экономики и либеральной демократии. В числе учредителей общества и первых активных деятелей, помимо экономистов, было немало других известных гуманитариев, таких как фрилософы и социологи Р. Арон, Б. де Жћувенель, M. Полани, К. Поппер, историк В. Веджвуд (единственная женщина среди учредителей) и др. Да и инициатор создания этого общества Ф. А. Хайек был к тому времени уже скорее социологом, политологом и даже фрилософром права, чем экономистом. Однако ко второй половине $60-\mathrm{x}$ гг. XX в. «Мон Пелерин» превратилось почти что в секту радикальных экономистов, «новых консерваторов», постепенно вытеснивших из своих рядов сначала почти всех неэкономистов, а затем и социально ориентированных собратьев вроде немецкого экономиста А. Рюстова.

По мнению уже упомянутого француза Б. де Жћувенеля, «Мон Пелерин» к середине 60-х гг. «все больше исповедует какое-то манихейство, согласно которому государство не способно сделать ничего хорошего, а частное предпринимательство - ничего плохого». Его члены отождествляли частное предпринимательство с индивидуальной свободой, благоговели перед абстрактной идеей корпораций, «у которых нет души, чтобы спасти, и нет тела, чтобы наказать». По мнению французского ученого, организация пала жертвой «идеологической страсти» и в результате «из свободного сообщества людей» превратилась в «сплоченную группу бойцов». По его утверждению, готовность «отважно сражаться достойна восхищения, но эти люди выковывают из интеллектуальной группы монолитную болванку» $[14$, с. 174,175$]$. Совсем не случайно «Мон Пелерин» в дальнейшем ассоциировалось только с экономистами - сторонниками рыночного фундаментализма, прежде всего американцами М. Фридманом, Д. Стиглером, Г. Беккером.

Между тем правоведение нуждается в исследовании пограничных с экономикой предметных зон, в том числе в историческом аспекте. Актуальность таких исследований будет только возрастать, но при равноправных и взаимно обогащающих подходах. Рискнем предположить, что потребности историков экономической мысли в этой части ничуть не меньше. Современные же попытки некоторых экономистов захватить «чужие территории» выглядят, как минимум, странно, а их рекомендации, обращенные к другим гуманитариям, по преобладающему мнению, либо банальны, либо смешны. Кстати, на взгляд практически всех специалистов по гуманитарным дисциплинам, да и большинства экономистов, экономика никогда не была и не будет естественной или точной наукой в силу того, что имеет дело не с молекулами, атомами, цифрами или фризическими телами. Имен- 
но фигура человека во всех его проявлениях (а не убогая пародия в лице «человека экономического»), а равно феномен человеческого сотрудничества делают экономику гуманитарной наукой, наряду со всеми остальными. Отчасти и поэтому основанные на математических моделях предсказания экономических гуру редко по точности отличаются от гадания на кофейной гуще, а сами предсказатели тратят гораздо больше времени на объяснения, почему их предсказания не сбылись.

Все вышесказанное позволяет заключить, что изучение истории правовой и экономической мысли во взаимодействии позволит со временем обогатить как знания в области права, так и в области экономики.

\section{Ссылки}

1. Лушников А. М. Право и экономика. М.: Проспект, 2019. 192 с.

2. Зантум У. Невидимая рука: экономическая мысль вчера и сегодня. М.: Мысль, 2017. 448 с.

3. Седлачек Т. Экономика добра и зла. В поисках смысла экономики от Гильгамеша до Уолл- Стрит. М.: Ад Маргинем Пресс, 2016. 544 с.

4. Шмоллер Г. Народное хозяйство, наука о народном хозяйстве и ее методы. Хозяйство, нравы и право. Разделение труда. М.: Изд.-во К. Т. Солдатенкова, 1902. 368 c.

5. Бернацкий M. В. Теоретики государственного социализма в Германии и социально-политические воззрения князя Бисмарка. СПб.: Типо-литография Шредера, 1911.489 с.

6. Туган-Барановский М. И. Очерки по новейшей истории политической экономии и социализма. СПб.: Тип. М. А. Александрова, 1907. 284 с.

7. Блауг М. Экономическая мысль в ретроспективе. М.: Дело Лтд, 1994. 687 с.

8. Ронкалья А. Богатство идей. История экономической мысли. М.: Ид ВШЭ, 2018. 656 c.

9. Тейлор Д. А. Адам Смит и неолиберальная экономика. СПб.: СПбГУ, 2016. $100 \mathrm{c}$.

10. Блауг М. Формалистическая революция 1950-х годов // Истоки: качественные сдвиги в экономической реальности и экономической науке. М.: ИД ВШЭ, 2015. С. 37-56.

11. Тироль ж. Экономика для общего блага. М.: Изд.-во И-та Гайдара, 2020. $696 \mathrm{c}$.

12. Чанг Х. Д. Как устроена экономика. М.: Манн, Иванов и Фарбер, 2018. 320 с.

13. Дюмон Л. Homo Aequalis. I. Генезис и расцвет экономической идеологии. M.: NotaBene, 2000. 240 c.

14. Бёргин Э. Великая революция идей. М.: Мысль, 2017. 327 с. 